PROBLEMS

OF EDUCATION

IN THE $21^{\text {st }}$ CENTURY

Vol. 76, No. 5, 2018

\title{
TRAINING APPROACHES FOR IMPROVING SCHOOL MANAGERS' CONFLICT RESOLUTION SKILLS: A CASE STUDY
}

\author{
Nyet Moi Siew \\ University Malaysia Sabah, Malaysia \\ E-mail: snyetmoi@yahoo.com \\ Scott Jones \\ Bjørknes University College, Norway \\ E-mail: meetingminds@gmail.com
}

\begin{abstract}
This research took a case study approach to researching the common conflicts faced by school managers, their sources, impacts and the approaches used to manage them. The research involved 18 in-service Malaysian school managers who undertook a 16-hour professional development workshop where they engaged with different conflict management tools. Data on participants' workplace experience in resolving conflicts were captured through written diaries collected before and two months after the workshop, and face-to-face semi-structured interviews during the following months. Intragroup conflicts due to goal incompatibility were the most common conflicts faced. Negative impacts of conflicts on school communities far outweighed the benefits. Participants reported that the most effective approaches to resolving workplace conflicts were sincere efforts in problem-solving coupled with (1) culturally relevant negotiations and coaching (e.g. using a GROW coaching model); (2) stakeholder and conflict analysis, to consider and respond to everyone's needs and feelings; and (3) reflecting on personal conflict management styles and adopting a positive attitude to personal and professional development. Certain elements in customary approaches such as respectful discussion and consultation were found relevant in resolving several of the participants' workplace conflicts. It is suggested that practical training courses on conflict management that build on people's strengths should be included in the curricula of further and higher education institutions and teacher training institutes.
\end{abstract}

Keywords: conflict management, conflict resolution, customary approaches, GROW coaching model, professional development workshop, school managers.

\section{Introduction}

Effective school management is integral to increasing educational standards. One cause for concern among school managers is the amount of effort needed to resolve common conflicts among primary and secondary school communities. In Malaysia, it is estimated that about 11/2 hours out of an 8-hour workday is devoted to resolving conflicts in an organization (Muhamad, 2001).

In most educational institutions, conflict management revolves around informal social processes that address conflict at an early stage and facilitate consensual resolutions to disputes (Saundry \& Wibberley, 2014). These processes are underpinned by high trust relationships between school managers and teachers. However, this approach can fail where staff cooperation and knowledge are low. At the same time, school managers who have responsibility for managing conflict sometimes lack the confidence and skill to deal with especially difficult issues (Luthans, 2011). 
Professional development in conflict management is therefore a strategic necessity to support managers in their efforts to successfully resolve school conflicts. Developing their skills and confidence is vital, with a shift in emphasis toward creative, relevant and achievable approaches to managing conflict. Involving school managers and teachers in taking appropriate, culturally relevant conflict management approaches can lay the basis for improved relationships among school community.

To address this, a professional development workshop for in-service school managers was undertaken to support teachers in managing their workplace conflicts. School managers were administrators who had teaching experience or responsibilities for educational content. Positive feedback from the workshop could be used as a basis for discussion for administrators to track and monitor the types and levels of conflict in their respective schools. As noted by Walraven (2003), one workshop or lesson, or even a series of lessons, is not sufficient to sustain results; participants need opportunities to practice their skills. The workshop involved repeated practice and simulations, with one-to-one follow-up support, interviews and diary writing. In addition, exploration into customary approaches (sometimes called 'traditional') used in school managers' communities could provide new insights into conflict resolution in the community. For the purpose of this research, customary approaches are mechanisms of conflict management that have their roots in indigenous communities and have been practiced in those societies over a considerable period. Including customary approaches to conflict, management can lead to greater participation and chances of success, than using only those approaches defined by the 'leaders' of the conflicting parties (Boege, 2011).

Although the importance of conflict management professional development workshops is recognised, there has been little research into their impact on resolving the conflict among Malaysian school managers. Several studies use quantitative approaches to investigate conflict management strategies, and task and goal interdependence related to conflict management among school teachers and managers (Lee, 2013; Mohd Tahir \& Abd Kadir, 2011). The causes of conflict and effective methods to conflict management have also been investigated (Salleh \& Adulpakdee, 2012).

However, existing studies do not explain the process of conflict management in schools, particularly the root causes of conflicts and how they are managed by school managers. To address this, the researchers used the training workshop to explore and understand the common conflicts faced by school managers, the impacts they experienced, and the conflict management approaches they adopted. Because conflict is personally experienced, the researchers were in direct contact with participants before, during and after the workshop. This action enabled researchers to appreciate participants' feelings, attitudes and beliefs about the conflicts they experience, the meanings they ascribed to those conflicts, and the rich context for their behaviour and activities (Denzin \& Lincoln, 2005). Therefore, the research adopted an interpretivist paradigm, since research findings would be drawn from the respondents' own experience and interpretation (Bryman 2004).

\section{Theoretical Framework}

\section{Kolb's Experiential Learning Theory}

Kolb (1984)'s experiential learning theory provided the theoretical framework in this study. Kolb defines learning as "the process whereby knowledge is created through the transformation of experience. Knowledge results from the combinations of grasping and transforming the experience" $(1984$, p. 41). In other words, experience plays a central role in the learning process. Kolb's experiential learning theory is typically represented by a four-stage learning cycle as depicted in Figure 1. 


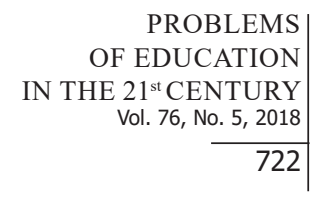

PROBLEMS

$21^{\text {st }}$ CENTURY

$\begin{array}{r}21^{\text {st }} \text { CENTURY } \\ \text { Vol. 76, No. 5, } 2018 \\ \hline 722\end{array}$

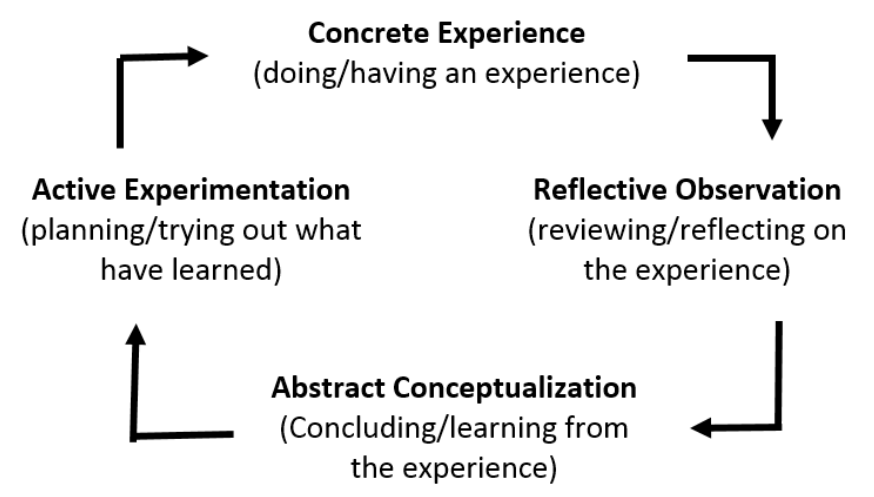

Figure 1. Kolb's Cycle of Experiential Learning (Kolb, 1984).

According to Kolb, effective learning requires a person to progress through a cycle of four stages: of (1) having a concrete experience followed by (2) observation of and reflection on that experience which leads to (3) the formation of abstract concepts (analysis) and generalizations (conclusions) which are then (4) used to trying out to the world around them.

In this research, Kolb's (1984) learning cycle was used to develop the conflict management workshop, and as a simple framework for school managers to (1) actively engage in 'hands-on' training in which they encountered new experiences of managing conflict, (2) reflect on any inconsistencies between their prior conflict management experience and understanding and the new ones, (3) reinterpret their prior experience of conflict management, and (4) consider any new action that could be taken into their school environment to revise the way a given conflict might be handled. This learning cycle also served as a guide for managers to write their diary by reflecting on their experiences of conflict, the workshop itself, and to discuss which tools or approaches best supported their post-training efforts to manage conflicts.

\section{Research Questions}

A professional development workshop was conducted to provide a training and learning platform for school managers to explore and apply conflict management skills relevant to their own situations. The guiding research questions were:

1. What are the common conflicts faced by school managers in schools?

2. What are the sources and the effects of conflicts on the school community?

3. How does a bespoke, professional conflict management workshop enable school managers to explore, understand and resolve the conflicts they experience?

4. What are the customary or traditional approaches used in school managers' communities to manage conflicts?

\section{Methodology of Research}

\section{Research Design and Participants}

The qualitative research design allowed researchers to 'focus on the interpretation' as well as 'to examine the way people think and act' (Ezzy, 2001). A case study approach was chosen (Hartley, 2004; Rowley, 2002; Yin, 2014) in which a professional, practical conflict management workshop was held over two days in October 2014 at a high school in Tawau, Sabah, Malaysia. Eighteen school managers from secondary and primary schools volunteered to engage with this research. The 10 males and 8 females were aged between 30 and 45 and 
had six to 25 years teaching experience in science and/or social science. The managers were appointed to join the workshop by the school principal on the basis of their academic and professional qualifications, teaching experience, work performance and leadership (School Divisions, 1989). The managers held different administration posts from Committee Heads to Head of Department.

The Workshop was conducted by an experienced conflict management facilitator from Mind the Gap Research and Training (UK). Working with local managers' knowledge, a local researcher was involved in decisions regarding workshop methods, content and tools. Topics included:

- Ways of looking at conflict and collaboration

- Structural and process conflicts; conflicts over personalities and interests; and latent conflict

- Relating conflicts to human needs

- Cultures of conflict management

- Customary approaches to problem solving in Sabah

- Conflict management styles

- Conflict analysis and mapping

- Stakeholder analysis

- Working with different types of power

- Principles of building consensus

- Effective communication - listening and asking high quality questions

- Negotiations

- Holding positive conversations

- Managing self and managing stress

- Giving and receiving effective feedback

- Creative thinking

- Coaching, self-coaching and using GROW and SCORE coaching models

The facilitation approach was participatory and interactive. Discussions, role plays and team exercises, drew on international examples of conflict management. Of particular interest was the way that the facilitation and 'hands-on' practice revealed to participants a wide range of situations and how to deal with them, with participants given opportunities to engage with conflict management tools in practical ways.

\section{Data Collection}

Qualitative data were gathered through participants' personal diaries. The researchers and a Malay language teacher translated guiding questions for these diaries into Malay (Table 1). Diaries have been regarded as a valued qualitative data collection instrument due to the richness, depth and extension of the information that they provide (Jacelon \& Imperio, 2005; Välimäki, Vehviläinen-Julkunen, \& Pietilä, 2007). Diaries allowed school managers to describe people and events from their school observations, and to reflect on their feelings and reactions to the conflictive situation.

Asked to comment on the questions' readability, all participants and an Education Management lecturer agreed that the questions were relevant and should remain in the research. Participants detailed their experience in a diary before and after the workshop. Diaries were collected eight weeks later, after practicing conflict management tools in their workplace. 


\section{PROBLEMS \\ OF EDUCATION \\ IN THE $21^{\text {st }}$ CENTURY \\ Vol. 76, No. 5, 2018 \\ 724 \\ Table 1. Guiding Questions used in diary writing to address the research questions.}

\begin{tabular}{|c|c|}
\hline $\begin{array}{l}\text { Research } \\
\text { Question }\end{array}$ & Guiding Questions \\
\hline & Pre-workshop \\
\hline \multirow[t]{2}{*}{1 and 2} & $\begin{array}{l}\text { Please describe a conflictive situation in your work before the training, in which you were involved } \\
\text { and which you did not manage well. What happened? }\end{array}$ \\
\hline & Post-workshop \\
\hline 3 & $\begin{array}{l}\text { Please describe a conflictive situation in your work, SINCE the training, in which you have used any } \\
\text { part of the training to help you manage the situation. Specifically, what did you do? What aspect of } \\
\text { the training did you use? Please describe, specifically and in some detail, how your actions, and your } \\
\text { learning from the training enabled the issue to be well managed?' }\end{array}$ \\
\hline \multirow[b]{2}{*}{4} & Post-workshop \\
\hline & $\begin{array}{l}\text { Please describe the customary or traditional approach used in your community to address conflicts. } \\
\text { What is this process called? What sort of conflicts is it used to address? Who leads the process or } \\
\text { is responsible for it? }\end{array}$ \\
\hline
\end{tabular}

Face-to-face, semi-structured interviews were conducted with eight of the participants during the months following the workshop. These eight were selected to cover all categories of the conflict management evenly, with two of them represented each category identified from the 'within and across all cases' analysis in stage 5 (Table 2). These lasted about 30-40 minutes and enabled individuals to reflect on their experiences of conflict, the workshop itself, and to discuss which tools or approaches had supported their post-training efforts to manage conflicts. There was no instruction to use one tool or another; participants were given the freedom and respect to use different tools as their work situation and personal comfort suggested. Interviews were audio taped and transcribed for analysis. The research lasted three months from October to December 2014.

\section{Ethical Considerations}

Participation in the research was voluntary. Prior to the workshop, participants were given a letter of consent detailing the nature of their involvement in the research. The research purpose was explained, and participants were assured of anonymity and the confidentiality of their response. To ensure anonymity, certain job categories and institution names have been changed. Throughout this paper, ' $\mathrm{P}$ ' followed by a number refers to a participant, rather than using names or institutions.

\section{Data Analysis}

Data were analysed through thematic analysis; a form of a pattern recognition technique by searching through the data for emerging themes (Fereday \& Muir-Cochrane, 2006). Firstly, the researchers made sense of each individual account in participants' written diaries and compared across those accounts to identify common themes. Thus, within-case and across-case strategies were integrated in the analysis, adapted from Ayres, Kavanaugh, and Knafl (2003). The steps are summarised in Table 2 . 
Table 2. Within-Case and Across-Case Analytic Strategies from written diaries.

\begin{tabular}{|c|c|c|}
\hline Strategy & Analytic Focus & Product \\
\hline Analytic immersion in 18 diaries & Within all cases & $\begin{array}{l}\text { Sense of conflict management lived experience } \\
\text { of respondents }\end{array}$ \\
\hline Immersion in each diary & Within each case & Identification of significant statements \\
\hline $\begin{array}{l}\text { Comparisons of significant state- } \\
\text { ments }\end{array}$ & Across cases & $\begin{array}{l}\text { Identify categories of statements } \\
\text { common to all participants }\end{array}$ \\
\hline $\begin{array}{l}\text { Reconnection of significant state- } \\
\text { ments to diaries }\end{array}$ & Within and across all cases & $\begin{array}{l}\text { Ascertain fidelity to original } \\
\text { accounts }\end{array}$ \\
\hline Intuiting, critical reflection & Within and across all cases & Identification of categories of conflicts \\
\hline Free writing & Within and across all cases & $\begin{array}{l}\text { Answer research questions (identification of } \\
\text { themes and codes) }\end{array}$ \\
\hline
\end{tabular}

After reviewing participants' written diaries and acquiring a feeling for their experiences, the researchers returned to each person's account to identify significant statements; phrases, sentences, or paragraphs that related directly to their experience of the conflictive situation and how they approached it. These statements were gathered and compared, paying particular attention to the commonalities across respondents (Steps 1-3, Table 2). Each significant statement was then reconnected to its original context of categories of conflicts and validated the categories (Step 4, Table 2) by referring works in literature review.

This strategy of moving between across-case and within-case comparisons enabled critical reflection on and identification of categories of conflicts (Step 5, Table 2), as they were found in the accounts of the multiple respondents (Swanson-Kauffman \& Schonwald, 1988). The researchers were able to make these categories of conflicts explicit through free writing, which is the final phase of intuiting (Step 6, Table 2). During free writing, the researchers responded to the research question, e.g. "What are the sources and the effects of conflicts on the school community?" with the reference of each category of conflict. The researchers then grouped the significant statements according to categories of conflict and developed a set of themes for each (conflict faced, source, effects, ways of managing conflict and outcomes) (Table 4, Appendix A). Codes were also drawn from respondents' accounts for each theme.

Next, the interview data were analysed using thematic analysis proposed by AttrideSterling (2011). Recorded interviews were listened to several times. This helped dissect the information into manageable, meaningful codes. A sheet was then prepared for each interview. The codes generated were labelled against the themes identified in diary entries.

Two researchers independently reviewed participants' diary entries and recorded interviews by reading/listening to the data line by line and identified recurring patterns. The patterns identified by each researcher were compared to ensure the validity of the codes/ themes/categories. The researchers dealt with codes/themes/categories which had no consensus by comparing and contrasting their perspectives in order to find common ground. Through multiple reviews and an iterative process, themes and codes were refined and grouped into categories of conflict. 
OF EDU

IN THE $21^{\text {st }}$ CENTURY Vol. 76, No. 5, 2018

726

\section{Results of Research}

\section{The Common Conflicts faced by School Managers in Schools}

Four common conflicts faced by school managers in schools were identified. These were: interpersonal conflict, intrapersonal conflict, intragroup conflict, and intergroup conflict as categorized by Dove (1998). Half the conflicts described were intragroup conflicts. Intrapersonal, interpersonal and intergroup conflicts each accounted for $17 \%$ of the conflicts described (Table 3). Examples of these are given below.

Table 3. Percentage of types of conflicts.

\begin{tabular}{lll}
\hline & No & $\begin{array}{l}\text { Percentage } \\
\text { (\% rounded up) }\end{array}$ \\
\hline Interpersonal & 3 & 17 \\
Intrapersonal & 3 & 17 \\
Intragroup & 9 & 50 \\
Intergroup & 3 & 17 \\
Total & 18 & 100 \\
\hline
\end{tabular}

Key Examples of Conflicts experienced by Participants

The four examples below provided an insight into the types of conflict faced by school managers, administrative authorities and school staff.

- Intragroup: Head of the Department conflict with the School Committee Chairpersons. This was framed as the Chairperson's failure to comply with Department head's instructions to prepare plans and annual activities; report any activities in the Teachers' Record Book, Annual Teaching Plans, Annual Report and Committee Planning for the year ahead. However, the requests and schedule for sending the reports were ignored creating conflict among the people involved.

- Interpersonal: A conflict between a Senior Teaching Assistant and a subordinate teacher. The subordinate teacher was unable to perform his duties well and this often triggered a variety of issues that caused conflict between the two parties.

- Intrapersonal: This example relates to teachers who left the classroom during their period of teaching in order to pick-up their children who attend private pre-schools. This disrupted teaching and learning, with the classrooms becoming unruly when the teacher was absent. This conflict also raised wider issues concerning classroom discipline, professional ethics, negatives views of the local community and the prestige of the teaching profession.

- Intergroup: This example relates to a misunderstanding between two parties with opposing views and decisions; a Senior Academic Assistant and a Senior Pre-U Assistant. Conflicts started from disputes over each party's jurisdiction over teachers which resulted in a duplication of duties. Neither administrator discussed the situation prior to detailing teachers' duties. As a result, teachers felt uncomfortable and confused in performing their tasks.

Sharing these conflicts in a professional, solution-focussed and non-blaming way, enabled the school managers to explore, understand and attempt to resolve the conflicts they experienced. 


\section{Intragroup Conflict}

Many diary entries and follow-up interviews regarded goal incompatibility as the main issue behind intragroup conflicts. This occurred mainly due to lack of co-operation, poor accountability and responsibility among committee members, and neglect or ignorance of duties and instructions. In turn, this often affected overall efforts to achieve the goals set by the school administration.

Indirectly, the activity or performance of one person in a group was described as affecting group performance. For example, Participant 3's (P3) experience of a conflict began when annual activity reports and teachers' record books were not submitted on time. This delayed their submission to the District Education Office. In the opinion of P3, the conflict had a strong basis in values and attitudes. P3 described the behaviours in strong language including unethical, disobedient, irresponsible, disrespectful, showing a lack of accountability and cooperation, and not giving their work sufficient importance and attention. One can easily see that feelings were running high and that it might not be easy to resolve such a conflict where a clash of values was so strongly felt.

In addition, intragroup conflicts were related in part to weak leadership skills and negative attitudes. Administrators were described as not always fully aware of the nature of the work, which puzzled and sometimes placed subordinates under stress. For example, in P9's experience as a specialist education (SE) officer, the goal was to spend $80 \%$ of their work hours a day to coach and mentor Level 1 Teachers. Although 80:20 task ratios were embodied in the Standard Operating Procedure for SE officers, this was described as "not taken seriously" by others, including SE colleagues. Participants also felt that other school specialists and SE Officers share the same scope of work but were treated differently and not well supported by their management.

Participant 7 (P7) wrote of a conflict that occurred due to miscommunication and misunderstanding about tasks and responsibilities of wardens and supervisors in the management of hostels. This conflict resulted in worsening management and administration of the dormitory.

Strong expressions in diary writing revealed that school managers experience negative emotions due to intragroup conflicts, including tension, uneasiness and feelings of insignificance. They relate this to low performance and team spirit in the group.

In contrast, conflicts could signal the start of constructive problem solving that increases the understanding and encourages respect among staff. P9 wrote,

"In this case, I needed to respect the feelings of my SE colleagues because they had the same responsibility and the need to work together to achieve the SE goal. The main key to success in achieving the aim was to understand their respective roles and respect the roles of others."

In resolving the intragroup conflict, most participants used coaching approaches to structure their thinking and conversations. Several referred specifically to their workshop practice with the GROW coaching model proposed by Whitmore (2009). With GROW, four important things are emphasised: the 'goal', 'reality', 'options' and 'what' which examines the methods to achieve the goals. For example, after coaching P3 became much more focussed on the goal - 'to ensure that Committee Heads submit their reports within two weeks.' He found it difficult to guarantee submission of the reports, but he still had a chance to change his approach to seeking timely submission.

As a result of the conflict-specific coaching, P3 concentrated less on the emotions he was feeling, and more on what he wanted to achieve and the process for getting there. He took a more team-focussed approach and researched the options that he could create. These included improved communication styles and having a solution-focussed approach that was more positive and supportive of others, yet firm and clear in his goals. One action involved holding an emergency meeting in which everyone was asked to give reasons why the reports 
OF EDUCATION

IN THE $21^{\text {st }}$ CENTURY Vol. 76, No. 5, 2018

728

could not be completed. Committee Heads were shown Ministry of Education instructions and a sample report so that they better understood the needs for reports and their timely submission. After this, repeated SMS requests for submission were sent to all Heads. P3 noted,



School managers also found stakeholder analysis useful. This tool revealed differing measures to solve the same problem. One participant re-examined who was involved in a particular management chain. These included checking whether a subordinate was a junior or senior teacher. Junior teachers had respect for the seniority of the leadership. P8 started the stakeholder analysis by assessing the causes of conflict, the attributes of the individuals involved and their goals, as well as the environment where communication takes place. The next step was to hold a joint meeting by giving a clear explanation and understanding related to the vision, achievements and expectations that the school and ministry were seeking. The last step was to execute the assigned instructions and tasks as well as possible.

A week later, according to $\mathrm{P} 8$, communication problems were solved. She evaluated this by noting her improved professional relationships and success in solving the problems that arose. These included equal coordination of tasks, more robust cooperation, payment of electricity and water bills, and better understanding of instructions among the employees. P8 said in follow-up interviews,

"um... all the staff had completed their work! This included update on the filing and documentation system, billing and payment issues and dorm food. Err....the management of the hostel was also awarded with the 'Best Management'HEM Award ... at the ... Year End Ceremony and Gala Dinner Appreciation. ...this was due to the conflict management workshop's influence."

\section{Interpersonal Conflicts}

In most cases, participants' diaries and follow-up interviews regarded interpersonal conflicts as a result of failures to demonstrate disciplined and good work ethics. For example, P4 was responsible for supervising teachers and the management of activities. However, she felt that one teacher often triggered a variety of issues such as lateness to class, absenteeism from committee meetings, late reporting of exam scores and failure to enter exam scores online.

Another conflict situation between P16 as Senior Teacher Assistant and a subordinate teacher was related to task delay, lack of responsibility and goal incompatibilities. For over six months and for vague reasons, the subordinate teacher did not submit his weekly teaching record book on time. Face-to-face discussion to guide the teacher did not bring any change.

According to P18, interpersonal conflict occurred in his school as a result of actions and attitudes of certain teachers who were less than collegial or cooperative. This had an impact on the performance of $\mathrm{P} 18$ as a specialism coordinator. The problem occurred because some teachers did not understand their responsibilities in that specialism or the Coordinator's workload. P18 said that as a result, some teachers did not perform their duties properly and some tasks had to be done by others. He described constant blaming between teachers about each other's responsibilities. The conflict caused P18 to feel uncomfortable with the school environment and made it difficult for daily tasks to be carried out. Such conflicts usually happened around examination week when student's papers had to be scored. P18 wrote that certain teachers who do not want to learn ICT skills would affect other teachers, forcing them to help or do their colleagues' duties.

Diary records and follow-up interviews recorded the disappointment, anger and stress between staff that this conflict created. These strong emotions made problems more complicated, difficult to discuss and hard to resolve. Negative thoughts and emotions were also 
reflected in low productivity and performance, a reduction in the achievement of school goals and breakdowns in staff relationships.

One administrator, P16 used workshop approaches more as a facilitator in this conflict. She applied the workshop training in consultation and negotiation to bring awareness to the parties in the interpersonal conflict. According to her, autocratic decision-making practices are less suitable in an organization because it affected subordinates' motivation. She said that through helping them improve their own consultation and negotiation skills, both sides were able to see how their stance gave rise to the conflict, and how to collaborate in identifying the most suitable option to solve it.

In another case, P18 reflected on the 'Conflict Management Styles' aspect of the workshop. She consciously moved away from 'Force' and 'Withdrawal' to try working with 'Collaboration' followed by 'Compromise' to manage her interpersonal conflict. Through actively and sincerely prioritising Collaboration over Force, P18 created both desire and opportunity to meet and discuss with the parties involved in the conflict and to enable consensus to resolve the conflict.

Actively working together to reconsider the most appropriate approaches to solving conflicts also resulted in improved communication among staff, and improved self-discipline and sense of responsibility. For example, P16 noted,

"Finally, the teacher submitted the letter to explain about his misdemeanour that had happened all year and admit his mistakes.".

P16 felt that she managed to educate the teacher to have a sense of responsibility through consultation and negotiation skills. Taking an approach based more on collaboration and compromise, P18 wrote that she was able to increase the level of trust between teachers and administrative staff, building a culture of shared responsibility, desire for change and also respecting the views and ideas of other colleagues.

\section{Intrapersonal Conflict}

The main reported sources behind intrapersonal conflicts were a sense of dissatisfaction about meeting individual desires and addressing one's own prejudices. One example is the tension of some female teachers who pick-up their children from preschool because their children cannot go to the same preschool where their parent(s) teach. Participants also describe intrapersonal conflicts due to poorly defined responsibilities, personal barriers and communication gaps. For example, P12 said,

"Owh, the absence of a list of specific tasks for Laboratory Assistants caused incoordination of job scopes among them. Ahh... new (inexperienced) Laboratory Assistants could not perform their jobs well .... As a result, the extension of this conflict caused (them) to ignore laboratory management affairs and had poor job performances. Ah, just like that lah..."

Participants described intrapersonal conflicts as producing negative emotions in subordinates resulting in frustration, failure to carry out duties, decreased teaching and learning quality, and decreased motivation and achievement. Poorly defined responsibilities caused confusion among subordinates on what should do. According to P12, without a clear job description or with multiple bosses (senior administrators and laboratory managers), subordinates would not understand their own work, were burdened with tasks outside their field of work and neglected their own work. This poor job performance, P4 added,

"affected ... motivation to perform tasks and (led to lab assistants) suffering from this internal conflict." 
Nyet Moi SIEW, Scott JONES. Training approaches for improving school managers' conflict resolution skills: A case study

PROBLEMS

OF EDUCATION

IN THE $21^{\text {st }}$ CENTURY Vol. 76, No. 5,2018

730

On the positive side, conflict was found in some cases to increase the sense of responsibility among school members and helped others perform better. Some school managers stepped in to mediate a conflict "instead of lingering on it." For example, P1 noted,

"immediate action towards the problem was crucial to prevent ... negative views from the local community towards the attitude of some teachers which could injure the dignity of the teaching profession."

P1 felt a responsibility to resolve the issue to maintain the good name of the profession as well as the school he worked for. P1 noted,

"Ah...I felt compelled to be a mentor in resolving the conflict, despite it did not involve me directly.". P2 felt similarly. "um... the focus is to find a way to assist the Laboratory Assistant to play an effective role in Laboratory Management."

These diary writings and follow-up phone interviews made it clear that the mentors who previously tried to win the dispute, now gave their best efforts to look for a compromise. They did this by reaching into learning about their own conflict management styles.

Most school managers appreciated the structure and clarity of purpose that came with coaching and open-minded discussions. Using a slightly more structured, outcome-focussed approach practiced through GROW conflict coaching, P1 wrote,

"The matter was discussed together as a sign of agreement for taking on responsibility if such problems arise again. Eventually, an agreement was attained between Headmaster and the staff which ultimately resolved the conflict."

\section{Intergroup Conflict}

Participants stated that intergroup conflict often arose due to managers' differing opinions or decisions concerning subordinates' duties. Participants reported that the managers did not consult each other to find common ground or unity of ideas. They described dealing with this conflict as very hard. For example, P6 noted,

"Administrators did not consult each other before distributing the tasks to avoid overlapping. This situation pressured me in my job performance and made me felt uncomfortable with my relationship with other colleagues."

The situation was worsened by weak coordination among school managers and lack of commitment in top management to resolve the conflict.

Another intergroup conflict related to differences in performance expectation. One trigger for inter-departmental conflict was strong inter-dependency with each other to accomplish a $\operatorname{task}(\mathrm{s})$. This was especially true for tasks that depended on sequential completion and differed in performance expectation. For example, in P14's situation, the Assessment and Examination unit could not perform their tasks on time when classroom teachers completed work late. In turn, classroom teachers were not able to perform their tasks when subject teachers had not keyed in the examination scores.

Participants P6, P11 and P14 observed that intergroup conflict in schools led to a number of negative impacts, along with a few positive impacts on school managers. The negatives included disappointment, mutual suspicion, poor relationships among colleagues, decreased motivation, and workplace tension and stress. On the positive side, resolving intergroup conflict was initiated by the staff concerned by understanding and absorbing personal differences, and building up tolerance. Participants stressed that conflicts needed to be faced and resolved quickly before they grew bigger and action by top-management became necessary. 
Most school managers drew on stakeholder analysis and coaching methods to support discussions between top-management and employees, analyse problems and consider alternative solutions. Improved approaches to giving and receiving feedback between the conflicting parties were also considered valuable workshop inputs that led to changes in the workplace. Participants reported that meetings were organised to open up discussions, clarify problems and seek suggestions. As the conflicting parties understood and accepted others' points of view, they worked toward compromise and reaching what one participant described as "a midpoint" between them. The process of navigating the 'give and take' of compromise helped build trust and positive relationships. This resulted in increased satisfaction in performing duties and improved ability to maintain positive relationships between junior and senior colleagues.

\section{Customary or Traditional Approaches used to address Conflicts}

Most participants belonged to the Bajau ethnic group. Diary entries revealed that when conflict occurs in their family or community usually the father, as the head (normally) of the family will guide face-to-face discussions at an early stage within the family. In a quarrel, parents talk to the individuals involved. However, if the problem cannot be solved within the family, help from others is requested, for example the village chief. The chief will call the parties together and offer several options or solutions, taking into account the views and needs of both parties. The chief then helps the parties agree from among those choices.

Participants noted that these solutions sit within 'adat' a broader framework of principles, values, traditional laws and conflict resolution processes that guide personal and community behaviour. Adat is a word of Arabic origin that roughly translates to 'custom' in Malay and Arabic. Adat was formally coded within the legally pluralistic Dutch East Indies (Burns, 1989) and Adat laws are formally part the legal system in Sabah in Malaysia's legal system (Sabah LawNet, 2016).

The important thing in 'adat' is family discussion, then consultation (village chief) and thirdly, agreement between the two parties. With this agreement, a decision is made to determine whether the guilty party will be fined (for a fee) and so on. Usually tolerance and solidarity among residents play an important role to overcome problems. However, participants (P4, P6, P9) noted,

"If the conflict does not reach consensus, then the courts are used to resolve the conflict through law"

According to participant 10, in certain community conflicts such as waste disposal issues, heavy vehicles entered the village and home-border issues, religious leaders play a role. This is because people easily accept the decision or opinion made by village priests who are highly respected by the community.

At a higher level, such as border disputes and land ownership, cases can be brought to the Native Court where law is based on the Indigenous Affairs Act. In this court, the District Chief or Native Chief has the power to penalties such as fines "... or other form of punishment recognised under native law or custom." (State of Sabah, 1992: Part 1:2). On the other hand, if the conflict is at a lower level, such as gossip or jealousy, according to P6, the community may employ a shaman as a mediator.

In sum, there are a variety of customary approaches to conflict management and dispute resolution. The most significant customs are based on adat which is rooted in long-standing and legally codified approaches in this part of Malaysia. The person-centred approaches and tools used in the conflict management workshop, with the emphasis on individual responsibility and group respect, found a strong fit with the values and culture of participants, and also with the customary approaches to conflict management and problem solving in their families and communities. 


\section{PROBLEMS \\ OF EDUCATION \\ IN THE $21^{\text {st }}$ CENTURY \\ Vol. 76, No. 5, 2018 \\ 732 \\ Discussion}

This research explored the types of conflict, their sources and effects, and conflict management approaches that were undertaken by school managers.

Intragroup conflict was the most common conflict people faced. This reduced team spirit, people's overall performance, and attainment of organisational goals. This is consistent with the findings of Cox (2005)'s study, which showed intragroup conflict had direct negative effects on team performance effectiveness. Goal incompatibility was identified as the main source of intragroup conflict. This involved a lack of cooperation among committee members concerning task accomplishment which affected the teams' goals. Weak leadership skills, miscommunication and misunderstanding relating to tasks and responsibilities were identified as triggers for intragroup conflict.

By applying the GROW model of conflict coaching, stakeholder analysis, and with a sincere approach to changing actions and problem solving, participants resolved several intragroup conflicts. Relationships also improved after some problems were resolved, notably the "small triumph" achieved in resolving late submission of reports Activity and Lesson Plans.

For participants involved in intrapersonal conflicts, a sense of dissatisfaction about meeting their own wishes and managing their own prejudices were described as sources of conflict. As a result, third party facilitation (participants called this mediation) was noted as an effective approach to helping reduce intrapersonal conflicts in the schools. This was also an effective way for school managers to acquire new ideas and points of view in helping conflict management in an organization. The third party could be anyone at any rank, depending on their suitability; school managers, department heads, or teachers.

Coaching and open discussion were also used to address intrapersonal conflicts before they developed into something more intractable. School managers felt that managers should properly define responsibilities and know how to interact with subordinates to develop effective cooperation and communications. They also felt that a good method of achieving school goals is not by using the force of their authority, but by understanding teachers' needs and working collaboratively with them to try to achieve individual and organisational goals.

In resolving interpersonal conflict, participants pointed out that the workshop's approach to reflecting on conflict management styles was relevant and helpful in developing selfawareness and confidence. Collaboration and negotiation skills were described as crucial for people to voice their different positions, and then to reach a consensus or compromise that was based on needs rather than forcefulness. Johnson and Johnson (1996) also perceive collaboration and negotiation to be the most constructive strategy to resolve a conflict.

In the case of school managers 'sandwiched' between two or more conflicting parties, attempts by the parties themselves to resolve intergroup conflicts was seen as crucial. By taking their own initiative to begin an open discussion, school managers managed to resolve incompatibilities and differing performance expectations. Compromises were reached which resulted in improved satisfaction in performing duties and improved relationships with all parties. This is in line with the functional view of organizational conflict that sees conflict as a productive force, one that can stimulate creativity, responsiveness and adaptability of the members towards a successful organization (Renner, 2007).

Recognizing school conflictive situations as intragroup, intergroup, intrapersonal and interpersonal conflicts helped clarify the differences and similarities among the conflicts that participants experienced. This categorisation also helped distinguish structural conflicts that needed administrative or cultural changes as part of their resolution, and personal conflicts where individual change and some courageous new responses formed part of solution finding.

It was clear that every school member or manager faced conflict in their daily work. Early, sincere efforts to identify approaches and actions to address conflicts were felt to be important not only to find long-term solutions but also to improve relationships and achieve individual and organisational goals. Participants also reflected on school conflicts having a 
number of negative impacts, along with a few positive impacts on school communities. For all participants, the many negative impacts far outweighed the benefits. Tackling conflict sensitively but courageously, rather than letting them "stew in the cooking pot" was an important observation made by several participants.

The research found that the three tools practiced in the workshop that were most helpful in managing conflict were sincere efforts in communications and problem-solving coupled with:

1. Culturally relevant structured dialogue and coaching (e.g. a GROW coaching model)

2. Using stakeholder analysis and broader conflict analysis, to consider and respond to everyone's needs and feelings; and

3. Reflecting on personal conflict management styles and adopting a positive attitude to personal and professional development.

Workshop approaches included culturally relevant, specific activities and practical tools that resonated with participants' real-world experience helped support them in managing their workplace conflicts. The training added to participants existing strengths, building on what they already did in ways that they could comfortably accommodate given their professional, personal and cultural experience. Practicing specific tools enabled them to build their confidence and skill in a safe but realistic environment.

It was also clear that customary approaches to conflict management and the general customs enshrined through Adat in participants' communities had a strong fit with the workshop approach and the tools used. Certain elements in the customary or traditional approach such as respectful discussion, fact-finding, consultation and a shared desire to find solutions mirrored the training and several tools and were also relevant in resolving several of the participants' workplace conflicts.

\section{Conclusions}

Taking an experiential learning approach in a practical conflict management workshop expanded school managers' insights in different approaches to managing conflicts in their schools and how to apply them. This research has highlighted the pivotal role of applying an experiential learning approach which has meaningful connections with the cultural, organisational and social norms of school managers and staff seeking to resolve conflicts. As affirmed by the results documented by participants in their diaries and in follow up interviews, effective management of fairly common conflicts in schools can be done by anybody who is sincere, comfortable and confident to use basic knowledge and skills of conflict resolution approaches. Success is even more likely with the help of those who are willing to assist in understanding and addressing conflicts through their organisational position; experience; familiarity with customary approaches; or collegial, supportive attitude. This research showed that successful conflict management not only resolved difficult situations but encouraged efficiency, dependability and professional ethics in the school environment.

Organizations like schools will always have conflicts for some of the reasons described in this study. These include incompatibility of goals (e.g. organisational vs individual goals; inter-departmental goals), high performance expectations, weak leadership skills, personal dissatisfaction, poorly defined responsibilities, and task delays. On the positive side, conflict need not bring harm to a school. This research also demonstrates that conflict is an important indicator for school managers and might better be treated as a catalyst for change in creating a more efficient, positive and less stressful organization. 


\section{PROBLEMS \\ OF EDUCATION \\ IN THE $21^{\text {st }}$ CENTURY \\ Vol. 76, No. 5, 2018 \\ 734 \\ Recommendations}

Recognizing that conflicts in schools are unavoidable, school managers and teachers can be supported through culturally appropriate, practical training in 'hands on' conflict management. Through this workshop, school managers were given opportunity to learn these things with respect for the people involved, and the nature and causes of the conflicts they faced. This enabled them to identify, assess and review the conflict in order to choose the most effective techniques for dealing with the issues in future. Practical courses incorporating experiential learning are more meaningful and effective if school managers and teachers are given an opportunity to experience a real conflict in safe ways, to build skills and confidence. It is implied that practical training courses on conflict management that build on people's strengths, and have cultural as well as personal and professional relevance, should be included in the curricula of further and higher education institutions and teacher training institutes.

\section{Acknowledgements}

The research was supported by the University of Malaysia Sabah (UMS), Malaysia under Grant No. GPP0004. Any opinions, viewpoints, findings, conclusions, suggests, or recommendations expressed are the authors and do not necessarily reflect the views of the University of Malaysia Sabah, Malaysia.

\section{References}

Attride-Stirling, J. (2001). Thematic networks: An analytic tool for qualitative research. Qualitative Research, 1 (3), 385-405.

Ayres, L., Kavanaugh, K., \& Knafl, K. A. (2003). Within-case and across-case approaches to qualitative data analysis. Qualitative Health Research, 13 (6), 871-883.

Boege, V. (2011). Potentials and limits of traditional approaches to peace building. In B. Austin, M. Fischer, \& H.J. Giessmann (Eds), Advancing conflict transformation: The Berghof handbook II. Opladen/Framington Hills: Barbara Budrich Publishers.

Bryman, A. (2004). Social research method. Oxford: Oxford University Press.

Burns, P. (1989). The myth of Adat. Journal of Legal Pluralism and Unofficial Law, 28, 1-127.

Cox, K. B. (2005). The effects of intrapersonal, intragroup, and intergroup conflict on team performance effectiveness and work satisfaction. Nursing Administration Quarterly, 27 (2), 153-163.

Denzin, N. K., \& Lincoln, Y. S. (2005). Handbook of qualitative research ( $2^{\text {nd }}$ Ed.). Thousand Oaks CA: Sage Publications.

Dove, M. A. (1998). Conflict: process and resolution. Nursing Management, 29 (4), 30-2.

Ezzy, D. (2001). Are qualitative methods misunderstood? Australian and New Zealand Journal of Public Health, 25 (4), 294-297.

Fereday, J., \& Muir-Cochrane, E. (2006). Demonstrating rigor using thematic analysis: A hybrid approach of inductive and deductive coding and theme development. International Journal of Qualitative Methods, 5 (1), 1-10.

Hanson, E. M. (1991). Educational administration and organizational behaviour. Boston: Simon and Schuster.

Hartley, J. (2004). Case study research. In C. Cassell \& G. Symon (Eds.), Essential guide to qualitative methods in organizational research. UK: Sage Publications.

Heifetz, R. A., \& Laurie, D. L. (1998). The work of leadership. In Rosenbach, W.E, Taylor, R.L., (Eds.), Contemporary issues in leadership (4 ${ }^{\text {th }}$ Ed., pp.179-194). Boulder: Westview Press.

Jacelon, C. S., \& Imperio, K. (2005). Participant diaries as a source of data in research with older adults. Quality Health Research, 15 (7), 991-997.

Johnson, D. W., \& Johnson, R. T. (1996). Conflict resolution and peer mediation programs in elementary and secondary schools: A review of the research. Review of Educational Research, 66 (4), 459506.

Kolb, D. A. (1984). Experiential learning: Experience as the source of learning and development. Englewood Cliffs, NJ: Prentice-Hall. 
Lee, L. J. (2013). Pengurusan konflik dalam kalangan guru di empat buah sekolah rendah Zon Tenang di daerah Segamat, Johor [Conflict management among teachers in four primary schools, Tenang Zone in Segamat, Johor]. Master Thesis, Universiti Teknologi Malaysia.

Luthans, F. (2011). Organizational behavior (12 ${ }^{\text {th }}$ ed.). New York: McGraw-Hill.

Mohd Tahir, L., \& Abd Kadir, N. (2011). Gaya pengurusan konflik guru dalam kalangan guru besar sekolah rendah Daerah Johor Bahru [Teacher conflict management style among the head of primary school teachers, Johor Bahru District]. Retrieved from http://eprints.utm.my/11974/1/ Gaya_Pengurusan_Konflik_Guru_Dalam_Kalangan_Guru_Besar_Sekolah_Rendah_Daerah_ Johor_Bahru.pdf.

Muhamad, J. (2001). Kelakuan organisasi [Organizational behavior] (4 ${ }^{\text {th }}$ ed.). Kuala Lumpur: Leeds Publications.

Nyamajiwa, B. M. (2000). Communication in negotiation. Harare: University of Zimbabwe Centre for Distance Education. Quality Health Research, 15 (7), 991-7.

Renner, J. (2007). Coaching abroad: Insights about assets. Consulting Psychology Journal: Practice and Research, 59, 271-285.

Rowley, J. (2002). Using case studies in research. Management Research News, 25 (1) 16-27.

Salleh, M. J., \& Adulpakdee, A. (2012). Causes of conflict and effective methods to conflict management at Islamic secondary schools in Yala, Thailand. International Interdisciplinary Journal of Education, $1(1), 15-22$.

Saundry, R., \& Wibberley, G. (2014). Workplace dispute resolution and the management of individual conflict - A thematic analysis of five case studies. London: Acas, 06/14. Retrieved from http://clok. uclan.ac.uk/10586/1/0614-Workplace-Dispute-Resolution-Thematic-Review.pdf.

Sabah LawNet. (2016). State of Sabah: Majlis Hal Ehwal Anak Negeri Sabah Enactment 1998 [Sabah State Affair Council Enactment 1998]. Retrieved from www.lawnet.sabah.gov.my/.../sabahlaws/ StateLaws/MajlisHalEhwalAnakNegeriSabah.

School Divisions. (1989). Professional circular letter No.4/1989. Kuala Lumpur: Ministry of Education Malaysia.

State of Sabah. (1992). Enactment to provide for the constitution, organisation and procedure of native courts, the jurisdiction and powers of such courts and matters relating thereto (No 3 of 1992).

Swanson-Kauffman, K. M., \& Schonwald, E. (1988). Phenomenology. In B. Sarter (Eds.), Paths to knowledge: Innovative research methods for nursing. New York: National League for Nursing.

Välimäki, T., Vehviläinen-Julkunen, K., \& Pietilä, A. M. (2007). Diaries as research data in a study on family caregivers of people with Alzheimer's disease: Methodological issues. Journal of Advanced Nursing, 59 (1), 68-76.

Whitmore, J. (2009). Coaching for performance: GROWing human potential and purpose - The principles and practice of coaching and leadership. ( $4^{\text {th }}$ ed.). Nicholas Brealey publishing: London.

Yin, R. K. (2014). Case study research: Design and methods ( $5^{\text {th }}$ ed.). Thousand Oaks, Ca: Sage.

Walraven, G. (2003). Conflicthantering en sociale competentie: vredeseducatie in de school [Conflict management and social competence: peace education in the school]. In Vriens, L. J. A., Kuijpers, J. M., \& Zoon, G. (Eds.), Nieuwe wegen voor vredeseducatie: Perspectieven voor de 21 eeuw [New ways for peace education: Perspectives for the $21^{\text {st }}$ century] (pp. 80-89). Amsterdam: SWP. 
Nyet Moi SIEW, Scott JONES. Training approaches for improving school managers' conflict resolution skills: A case study

PROBLEMS

OF EDUCATION

IN THE $21^{\text {st }}$ CENTURY

Vol. 76, No. 5, 2018

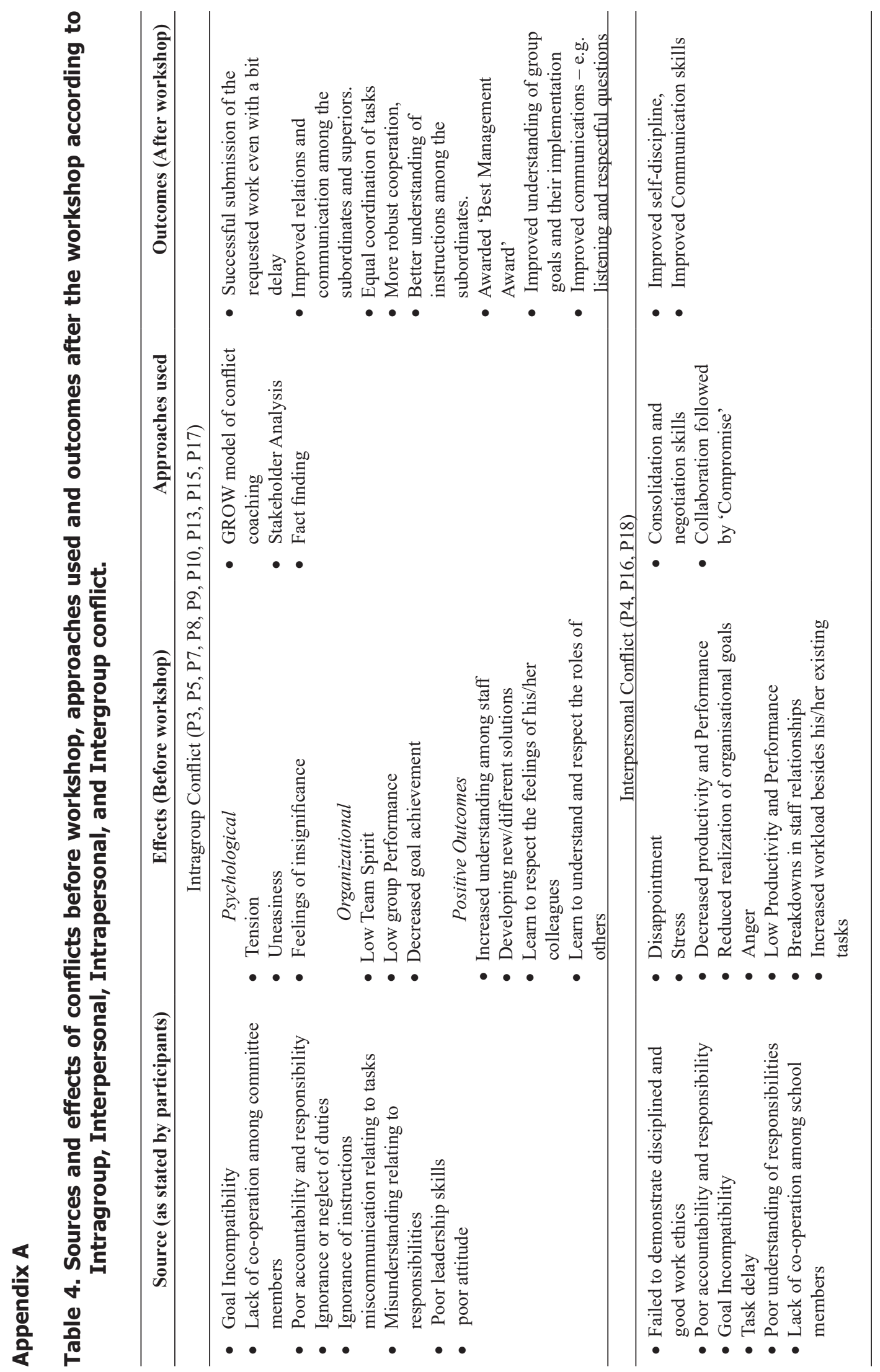





No. 5,2018
品
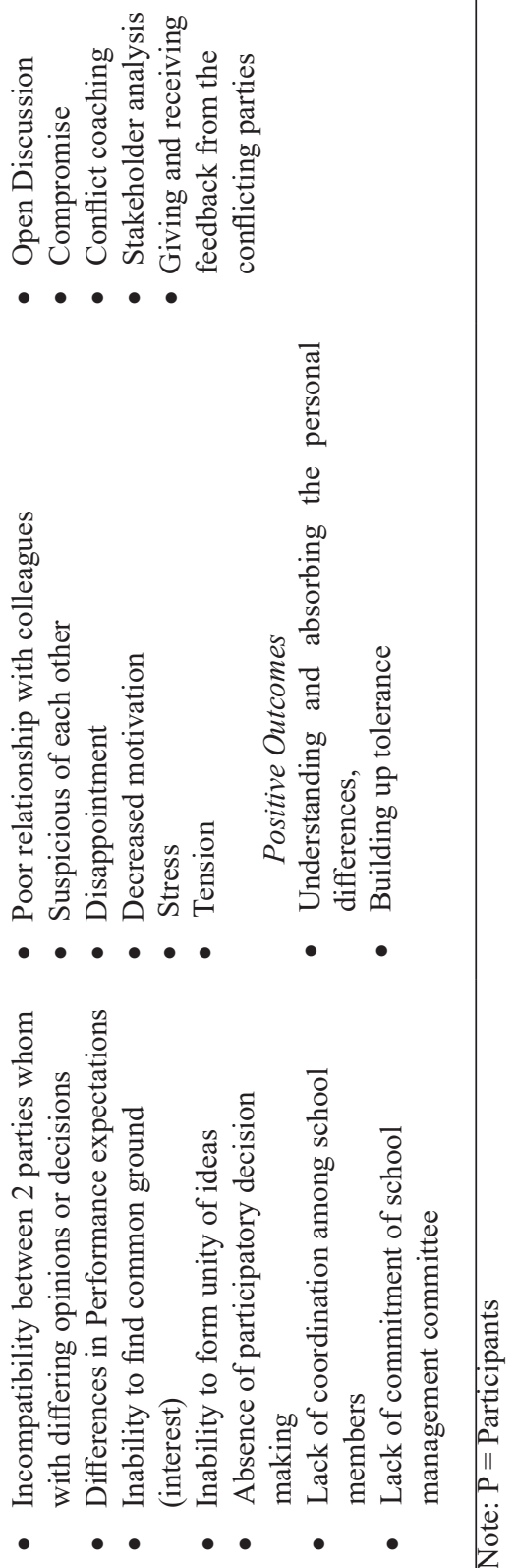
Nyet Moi SIEW, Scott JONES. Training approaches for improving school managers' conflict resolution skills: A case study OF EDUCATION IN THE $21^{\text {st }}$ CENTURY Vol. 76, No. 5,2018

Received: July 31, 2018

Accepted: October 05, 2018

Nyet Moi Siew PhD, Senior Lecturer, Faculty of Psychology and Education, University Malaysia Sabah, Jalan UMS, 88400, Kota Kinabalu, Sabah, Malaysia. E-mail: snyetmoi@yahoo.com

Scott Jones

Associate Professor, Peace and Conflict Studies, Bjørknes University College, Oslo, Norway.

E-mail: meetingminds@gmail.com 